\title{
Functional Capacity Improvement on Patent Ductus Arteriosus with Pulmonary Arterial Hypertension: A Case Report and Literature Review
}

Annis Rakhmawati*, Irsad Andi Arso, Anggoro Budi Hartopo, Lucia Kris Dinarti

\author{
Department of Cardiology and Vascular Medicine, Faculty of Medicine, Public Health and Nursing, Universitas Gadjah Mada - \\ Dr. Sardjito General Hospital, Yogyakarta, Indonesia \\ ${ }^{*}$ Corresponding author: \\ Annis Rakhmawati, MD, - email: coronagracilis@gmail.com \\ Department of Cardiology and Vascular Medicine, Faculty of Medicine, Public Health and Nursing, Universitas Gadjah \\ Mada - Dr. Sardjito Hospital \\ Jalan Farmako Sekip Utara, Yogyakarta, Indonesia 55281
}

Manuscript submitted: July 1, 2018; Revised and accepted: August 27, 2018

\begin{abstract}
Pulmonary artery hypertension (PAH) is a pathophysiological disorder involving a wide range of clinical conditions. This can be a condition of complications from heart disease and respiratory system. Pulmonary arterial hypertension is defined as an increase in mean pulmonary arterial pressure $(\mathrm{mPAP}) \geq 25 \mathrm{mmHg}$ at rest assessed by right heart catheterization. The cardiovascular rehabilitation program is a set of efforts to improve the underlying cause of cardiovascular disease such that it can maintain or restore the best conditions and secondary prevention. Cardiac rehabilitation and physical exercise programs have the benefit of improving pulmonary vascular endothelial function, physical activity capacity and quality of life parameters for PAH patients. A 6-minute walk test can be used to assess the functional capacity of PAH patients.
\end{abstract}

Keywords: pulmonary artery hypertension; functional capacity; 6-minute walk test

\section{INTISARI}

Hipertensi arteri pulmonal (PAH) adalah gangguan patofisiologis yang melibatkan berbagai kondisi klinis. Ini bisa menjadi kondisi komplikasi dari penyakit jantung dan sistem pernapasan. Hipertensi arteri pulmonal didefinisikan sebagai peningkatan mean Pulmonary Artery Pressure (MPAP) $\geq 25 \mathrm{mmHg}$ saat istirahat dinilai dengan kateterisasi jantung. Program rehabilitasi kardiovaskular adalah serangkaian upaya untuk memperbaiki penyebab penyakit kardiovaskular yang dapat mempertahankan atau memulihkan kondisi terbaik dan pencegahan sekunder. Rehabilitasi jantung dan program latihan fisik memiliki manfaat meningkatkan fungsi endotel vaskular pulmonal, kapasitas aktivitas fisik dan parameter kualitas hidup untuk pasien $\mathrm{PAH}$. Tes berjalan 6 menit dapat digunakan untuk menilai kapasitas fungsional pasien HAP. 


\section{INTRODUCTION}

Pulmonary artery hypertension $(\mathrm{PAH})$ is characterized by an increase in pulmonary vascular resistance that lead to decrease right ventricular function or death. ${ }^{1}$ In addition to medical therapy for $\mathrm{PAH}$, there are studies of cardiovascular rehabilitation programs and physical exercise programs in $\mathrm{PAH}$ patients that have positive effects because these programs can improve endothelial function, physical activity capacity, and life quality parameters. ${ }^{2}$ These programs include a series of physical, educational, psychosocial and secondary prevention activities. $^{3}$ This case reports the improvement of functional capacity in patient with patent ductus arteriosus (PDA) bidirectional shunt with $\mathrm{PAH}$, by means of home-based exercise program.

\section{CASE PRESENTATION}

A 23-year-old woman came with postpartum shortness of breath. She was reffered from a district hospital with a suspicion of atrial septal defect (ASD) on P1A0 5 days postpartum. Shortness of breath was felt since 32 weeks of gestation that increased during activity, improves at rest. The legs were swollen and the activity was limited. Patient routinely checked the pregnancy at local Primary Health Care and was advised to give birth at a district hospital due to suspicion of congenital heart disease. She delivered normally; the baby was in a good condition. After delivery her baby, her complain about shortness of breath and swollen legs still persisted, therefore she was referred to Dr. Sardjito General Hospital for further treatment. History of fatigue had been felt since childhood, no disturbance of growth. At 9 years old of age, she visited a cardiologist and was diagnosed with congenital heart disease. She was advised to do a surgery due to congenital heart disease then, but the patient's family were refused.

On physical examination, we found that she was compos mentis. The blood pressure was $120 / 70 \mathrm{mmHg}$, heart rate 95 beats per minute (bpm), respiration rate 32 times per minute and temperature 36.5 ${ }^{\circ} \mathrm{C}, \mathrm{SpO}_{2} 86 \%$. Jugular venous pressure was $2 \mathrm{cmH}_{2} \mathrm{O}$, no lymphadenopathy. Examination of the lungs showed vesicular voices in both the lung fields, there was no rales. Cardiac examination revealed cardiomegaly, prominent right ventricle heaving, continuous murmur in left infraclavicle area. Examination of both lower extremities showed peripheral edema.

The laboratory showed hemoglobin $13.3 \mathrm{~g} / \mathrm{dL}$, platelet $261 \times 10^{3} / \mu \mathrm{L}$, hematocrit $41 \%$, leukocyte $12.63 \times 10^{3} / \mu \mathrm{L}$, creatinin 0,96 mg/dL, SGOT $58 \mathrm{U} / \mathrm{L}$, SGPT $59 \mathrm{U} / \mathrm{L}$. Blood gas analysis $\mathrm{FiO}_{2} 70 \%, \mathrm{pH} 7.54$, $\mathrm{PO}_{2} 51.5 \mathrm{mmHg}, \mathrm{PCO}_{2} 22,7 \mathrm{mmHg}, \mathrm{HCO}_{3}$ $19.6 \mathrm{mEq} / \mathrm{L}, \mathrm{AaDO}_{2} 412, \mathrm{SO}_{2} 50.7 \%, \mathrm{PO}_{2}$ / $\mathrm{FiO}_{2}$ 75.3.

Electrocardiography at emergency department of Dr. Sardjito Hospital showed sinus rhythm, heart rate 95 beats/min, right axis deviation, right ventricle enlargement (figure 1).

Chest X-ray showed cardiomegaly with enlargement of right atrium and right ventricle, pulmonary hypertension and right lung partial infiltrate due to pneumonia (Figure 2).

The transthoracal echo cardiography showed bi directional shunt PDA diameter $10.26 \mathrm{~mm}$, dilated RV, LV D shaped, LV ejection fraction $75 \%$, normal LV diastolic function, decrease of RV systolic function (TAPSE $13 \mathrm{~mm}$ ), severe tricuspid regurgitation (TVG $66 \mathrm{mmHg}$ ), high probability $\mathrm{PH}$ (mPAP $26 \mathrm{mmHg}$ ) (Figure 3).

The patient was diagnosed as bidirectional shunt PDA with PAH. During treatment, the patient's condition was improved. Patient underwent 6 minutes walking distance (6MWD) before discharge. Before 6MWD, her blood pressure was $88 / 61 \mathrm{mmHg}$, HR $100 \mathrm{bpm}$, $\mathrm{SpO}_{2}$ upper limb 88\%, $\mathrm{SpO}_{2}$ lower limb $52 \%$. After 6MWD, her blood pressure was 99/66 mmHg, $\mathrm{HR} 110 \mathrm{bpm}, \mathrm{SpO}_{2}$ upper $\operatorname{limb} 82 \%, \mathrm{SpO}_{2}$ lower limb 51\%. She could reach 90 meters, it was equivalent to 1.42 mets. 
Patient was educated about homebased exercise to walk 30 minutes/day, 57 times/week accompanied by observing $\mathrm{SpO}_{2}$ before and after exercise. The exercise should be stopped when the patient feel shortness of breath or decrease of $\mathrm{SpO}_{2}>10 \%$ from the baseline (before exercise) or fatigue (Table 1). Evaluation of the exercise should be done in 4 weeks. The patient was discharged and received sildenafil $40 \mathrm{mg}$ t.i.d, bosentan $12.5 \mathrm{mg}$ b.i.d, furosemide $40 \mathrm{mg}$ q.i.d, and spironolacton $25 \mathrm{mg}$ q.i.d.

\section{DISCUSSION}

Pulmonary hypertension $(\mathrm{PH})$ is a pathophysiological disorder involving a wide range of clinical conditions and can be a complication of heart disease and respiratory system. Pulmonary hypertension is defined as an increase in mean pulmonary arterial pressure (mPAP) $\geq 25 \mathrm{mmHg}$ at rest and assessed by heart catheterization. ${ }^{1}$ Pulmonary hypertension is classified into five major groups. They are $\mathrm{PAH}, \mathrm{PH}$ due to left heart disease, $\mathrm{PH}$ due to chronic lung disease and or hypoxic conditions, $\mathrm{PH}$ due to chronic thromboembolic disease or other pulmonary artery obstruction, and $\mathrm{PH}$ of unknown cause. ${ }^{1} \quad$ Echocardiography studies found that the prevalence of $\mathrm{PH}$ is $10.5 \%$, including $\mathrm{PH}$ from left heart disease $78.7 \%$, $\mathrm{PH}$ of lung disease and hypoxia $9.7 \%, \mathrm{PAH} 4.2 \%$ and $\mathrm{PH}$ due to chronic thromboembolism $0.6 \%$ with average mortality in cases of $\mathrm{PH}$ are 4.5 to 12.3 per 100,000 population. ${ }^{1}$

There are many pathophysiology mechanism involved in the cell and tissue level of $\mathrm{PAH}$. The overall interaction of initiation and progression of the pathology process is not well understood. Hemodynamic changes of $\mathrm{PAH}$ patients are associated with complex pathophysiology and multifactorial pathobiology involving multiple biochemical pathways. Increased of pulmonary vascular resistance (PVR) is associated with vasoconstriction, proliferation, pulmonary vascular wall obstruction, inflammation, and thrombosis. This change involves endothelial cells, smooth muscle cells and adventitial resident cells. ${ }^{4}$ In adventitial layer, there is increase of extracellular matrix production including collagen, elastin, fibronectin and tenacillin. ${ }^{1}$ Inflammatory cells and platelets (via serotonin pathway) also play a role in the pathophysiology of $\mathrm{PAH}^{1}$

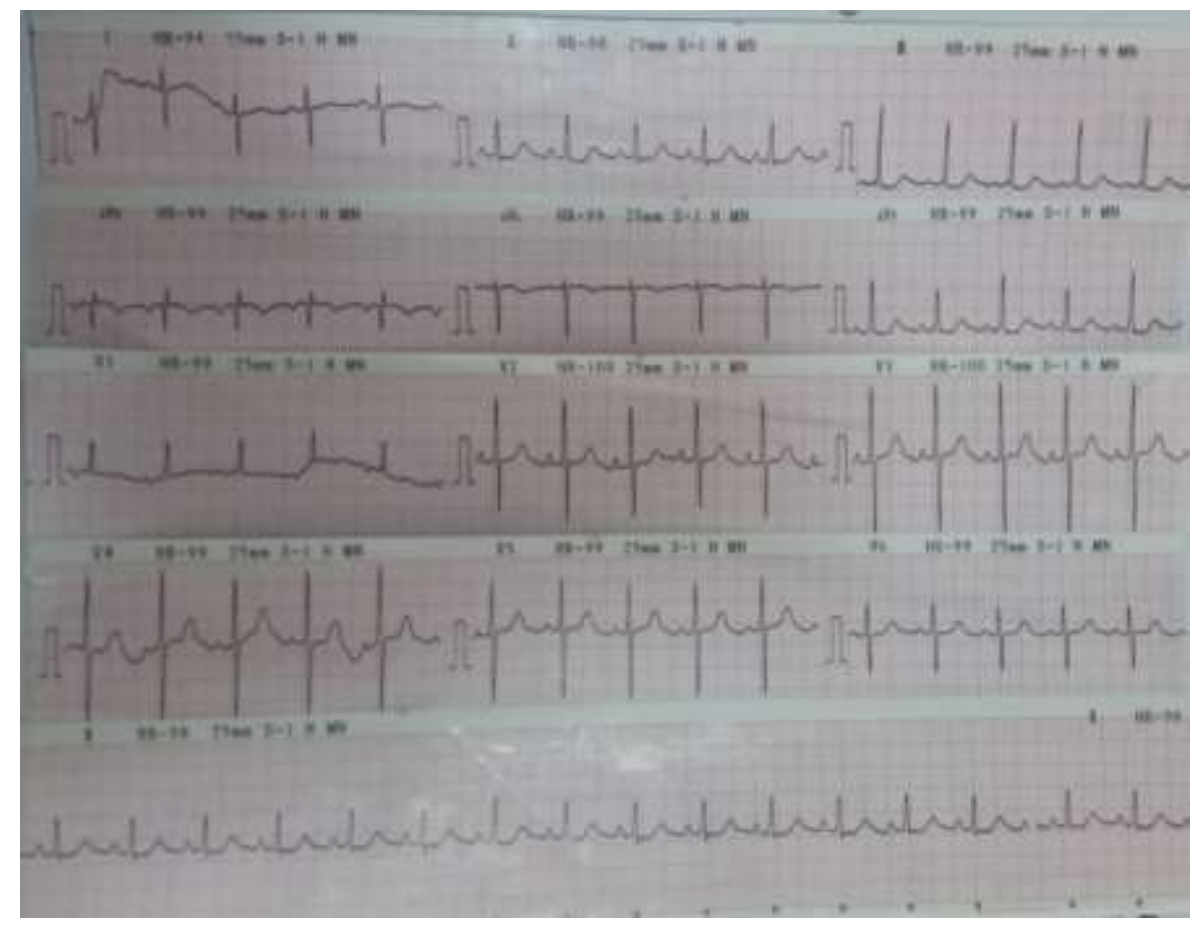

Figure 1. Electrocardiography found sinus rhythm, heart rate 95 beats/min, right axis deviation, right ventricle enlargement. 
Symptoms of PAH include shortness of breath during activity, decreased tolerance to physical activity, chest pain and syncope. They substantially decreased quality of life and experienced shortness of breath then decreased tolerance to physical activity or exercise. This condition occurs due to disruption of the gas exchange process associated with ventilation-perfusion mismatch as well as decreased pulmonary venous return flow resulting in decreased cardiac output. ${ }^{4}$ These result in hypoxia, decreased oxygen delivery to muscle, decreased maximal oxygen consumption, anaerobic metabolism and ultimately increased ventilation. ${ }^{4}$ The patient complained of fatigue during activity since childhood and shortness of breath since 32 weeks of gestation.

There have been many studies of medical therapy on $\mathrm{PAH}$, but there are also other studies suggest that cardiovascular rehabilitation and physical exercise program have the benefit of improving pulmonary vascular endothelial function, physical activity capacity and quality of life of $\mathrm{PAH}$ patients. ${ }^{2}$ Cardiovascular rehabilitation programs are a set of efforts undertaken to improve the underlying cause of heart disease, the physical, mental and social conditions of patients or who have a risk of cardiovascular disease than perform secondary prevention. Its goals are restoring the patient with heart disease or risk factors for heart disease as soon as possible to an active and productive life, maintaining the patient's best condition, stop or slow the progression of cardiovascular disease process and reduce the risk of mortality and morbidity of heart disease. ${ }^{3}$

Implementation of cardiovascular rehabilitation program consists of 4 phases, they are phase I, phase II, phase III and phase IV. Phase I program is a rehabilitation program conducted to patients who are still hospitalized. In this phase, the rehabilitation program is conducted in inpatient room until the patient is discharge in order to overcome or reduce the negative effects of bed rest during hospitalization, reduce the anxiety or depression problems caused by the illness and the patient is able to perform basic activity daily life. ${ }^{3}$ The programs include education of the patient's condition, gradual mobilization, physiotherapy according to the patient's condition as well as evaluation of fitness level and stratification ability before discharge. ${ }^{5} \quad$ In this case, during hospitalization, patients and family were educated about the patient's condition, gradual mobilization begins by sitting, walking around the bed and bathroom as well as around the treatment room.

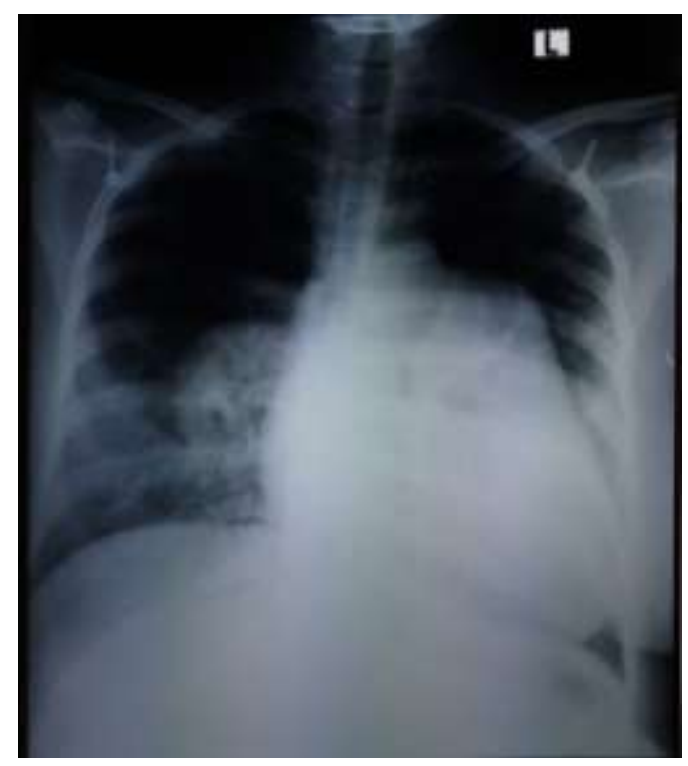

Figure 2. Chest $X$-ray showed cardiomegaly with enlargement of right atrium and right ventricle, pulmonary hypertension and right lung partial infiltrate due to pneumonia. 
Table 1. The result of home based exercise datasheet performed by patient and supervised by family member

\begin{tabular}{|c|c|c|c|c|c|c|c|c|}
\hline \multirow[t]{2}{*}{ Day } & \multirow[t]{2}{*}{$\begin{array}{l}\text { Distance } \\
\text { (meters) }\end{array}$} & \multirow[t]{2}{*}{$\begin{array}{c}\text { Duration } \\
\text { (minutes) }\end{array}$} & \multirow{2}{*}{$\begin{array}{c}\text { HR } \\
\text { before } \\
\text { exercise } \\
\text { (bpm) }\end{array}$} & \multirow{2}{*}{$\begin{array}{c}\text { HR after } \\
\text { exercise } \\
\text { (bpm) }\end{array}$} & \multicolumn{2}{|c|}{$\begin{array}{l}\text { Sp02 before } \\
\text { exercise (\%) }\end{array}$} & \multicolumn{2}{|c|}{$\begin{array}{l}\text { Sp02 after } \\
\text { exercise (\%) }\end{array}$} \\
\hline & & & & & $\begin{array}{l}\text { Upper } \\
\text { Limb }\end{array}$ & $\begin{array}{l}\text { Lower } \\
\text { Limb }\end{array}$ & $\begin{array}{l}\text { Upper } \\
\text { Limb }\end{array}$ & $\begin{array}{l}\text { Lower } \\
\text { Limb }\end{array}$ \\
\hline 1 & 90 & 30 & 100 & 110 & 88 & 52 & 82 & 51 \\
\hline 2 & 95 & 30 & 90 & 100 & 89 & 53 & 83 & 53 \\
\hline 3 & 90 & 30 & 100 & 110 & 88 & 53 & 83 & 51 \\
\hline 4 & 100 & 30 & 90 & 120 & 90 & 52 & 84 & 52 \\
\hline 5 & 90 & 30 & 86 & 100 & 88 & 52 & 83 & 51 \\
\hline 6 & 110 & 30 & 90 & 110 & 87 & 53 & 83 & 52 \\
\hline 7 & 130 & 30 & 84 & 100 & 89 & 53 & 83 & 53 \\
\hline 8 & 100 & 30 & 80 & 110 & 88 & 52 & 82 & 51 \\
\hline 9 & 120 & 30 & 90 & 110 & 88 & 53 & 83 & 51 \\
\hline 10 & 150 & 30 & 80 & 120 & 90 & 53 & 83 & 52 \\
\hline 11 & 180 & 30 & 80 & 110 & 89 & 53 & 83 & 53 \\
\hline 12 & 210 & 30 & 90 & 120 & 89 & 53 & 83 & 53 \\
\hline 13 & 200 & 30 & 86 & 100 & 87 & 53 & 83 & 52 \\
\hline 14 & 200 & 30 & 90 & 110 & 88 & 53 & 83 & 51 \\
\hline 15 & 210 & 30 & 84 & 100 & 88 & 52 & 82 & 51 \\
\hline 16 & 240 & 30 & 80 & 110 & 88 & 53 & 83 & 51 \\
\hline 17 & 260 & 30 & 90 & 110 & 88 & 52 & 82 & 51 \\
\hline 18 & 240 & 30 & 80 & 120 & 89 & 53 & 83 & 53 \\
\hline 19 & 280 & 30 & 80 & 110 & 88 & 53 & 83 & 51 \\
\hline 20 & 310 & 30 & 90 & 120 & 90 & 52 & 84 & 52 \\
\hline 21 & 300 & 30 & 80 & 100 & 90 & 52 & 84 & 52 \\
\hline 22 & 350 & 30 & 80 & 110 & 87 & 53 & 83 & 52 \\
\hline 23 & 350 & 30 & 80 & 110 & 89 & 53 & 83 & 53 \\
\hline 24 & 400 & 30 & 90 & 110 & 88 & 52 & 82 & 51 \\
\hline 25 & 400 & 30 & 80 & 90 & 88 & 53 & 83 & 51 \\
\hline 26 & 430 & 30 & 80 & 100 & 90 & 53 & 83 & 52 \\
\hline 27 & 430 & 30 & 100 & 110 & 87 & 53 & 83 & 52 \\
\hline 28 & 450 & 30 & 90 & 110 & 89 & 53 & 83 & 53 \\
\hline 29 & 500 & 30 & 80 & 100 & 88 & 52 & 82 & 51 \\
\hline 30 & 500 & 30 & 80 & 100 & 89 & 53 & 83 & 53 \\
\hline
\end{tabular}

The phase II program is a rehabilitation program for patients after returning home for secondary prevention, preparing the patient to return to work, perform optimal daily activities and make the exercise program safely and effectively for the patient. ${ }^{5}$ Training programs conducted in this phase include education and counseling for patients and family, controlling for patient risk factors, prescribing and implementing physical exercise programs, evaluating the ability or level of fitness of the patient, and occupational physiotherapy programs. The duration of exercise in phase II is 1-2 months in 12 practice sessions. ${ }^{6}$ In this case, after returning home, she was educated for home based exercise with prescription from the hospital. Evaluation was done within 30 days post discharge.

The phase III program is a further rehabilitation program after undergoing an evaluation of the Phase II program. Rehabilitation at this phase can be performed at cardiac and vascular rehabilitation centers or at home. This phase aims to continue the program to overcome disease progression, optimize physical exercise and continue healthy lifestyle independently. ${ }^{6}$ 


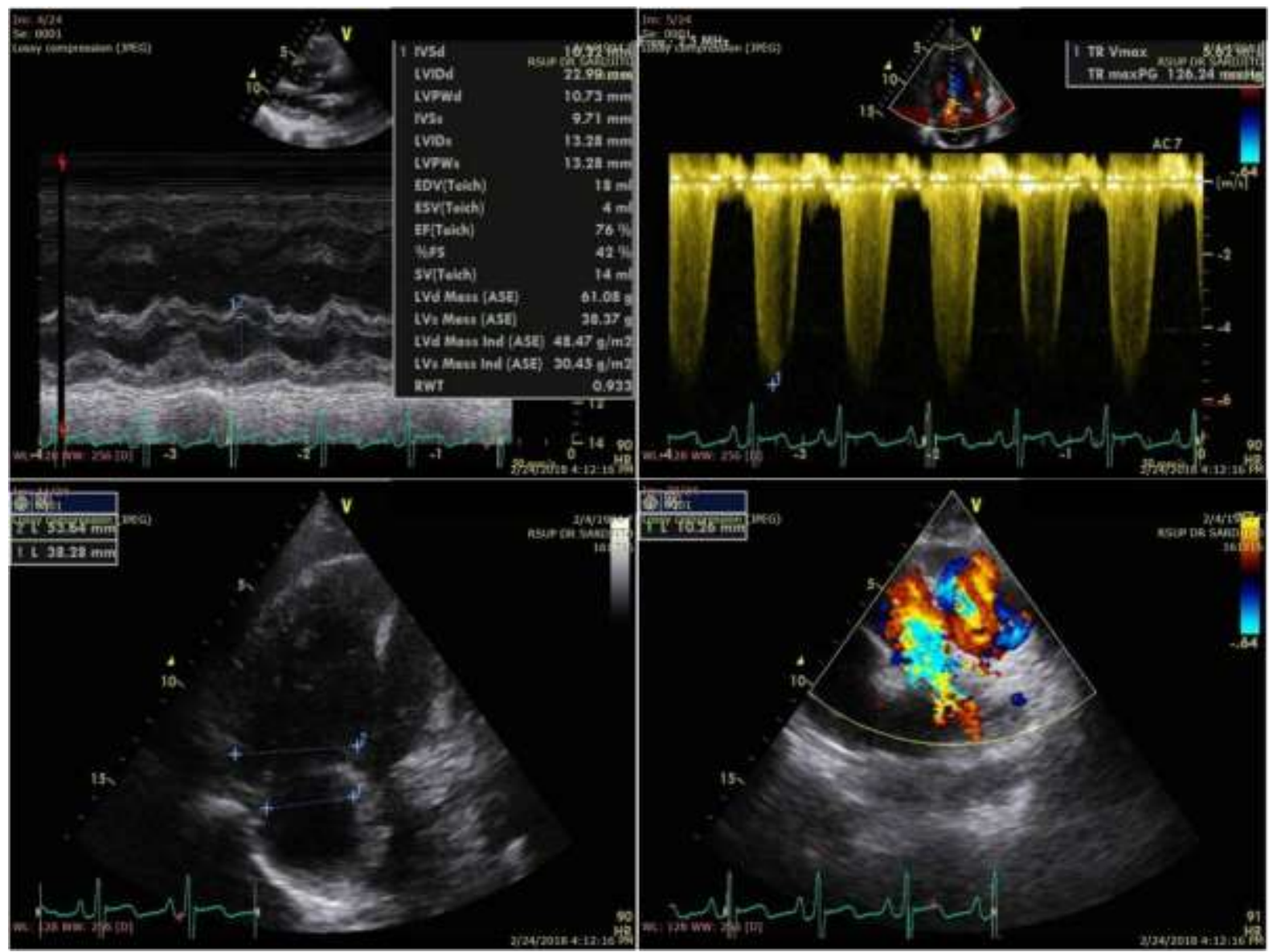

Figure 3. Transthoracal echocardiography examination showed bidirectional shunt PDA diameter $10.26 \mathrm{~mm}$, dilated RV, LV D-shaped, LVEF 75\%, normal LV diastolic function, TAPSE 13 $\mathrm{mm}$, severe tricuspid regurgitation (TVG $66 \mathrm{mmHg}$ ), high probability PH (mPAP $26 \mathrm{mmHg}$ ).

Programs in Phase III include counseling and education for patients and family, controlling risk factors for patients, measuring fitness and advanced physical exercise programs, outdoor exercise, functional level evaluation and further programs as well as advanced physiotherapy, occupational therapy and other necessary interventions. The duration of the Phase III is $1-3$ months. ${ }^{6}$ In this case, a phase III rehabilitation program had not been evaluated yet. The phase IV program is a rehabilitation program conducted independently by the patient. This program can be done at home or in a community environment such as in a heart healthy club. The purpose of phase IV is to maintain the patient's health condition at the most optimal level. The length of the program is a lifetime of patients with regular fitness level evaluations every 6 to 12 months. ${ }^{7}$ In this case, the phase IV rehabilitation program had not been implemented yet.
Physical cardiovascular rehabilitation program should consider the contraindications for physical exercise. These include unstable angina pectoris, systolic blood pressure $\geq$ $200 \mathrm{mmHg}$ and diastolic $\geq 100 \mathrm{mmHg}$, decreased systolic blood pressure $\geq 20$ $\mathrm{mmHg}$ from daily average blood pressure, moderate to severe aortic valve stenosis, uncontrolled ventricular heart rhythm disorders, uncontrolled tachycardia (heart rate $\geq 120$ beats/minute), uncompensated congestive heart failure, total atrioventricular block without a pacemaker, acute pericarditis, acute myocarditis, new embolism, thrombophlebitis, ST depression $\geq 2 \mathrm{~mm}$ on resting ECG, and presence of limb problems that cause the patient can't perform physical exercise. ${ }^{7} \mathrm{PAH}$ itself is not a contraindication for physical exercise. In this case, there was no contraindication to perform physical exercise. 
Cardiovascular rehabilitation and physical exercise programs in $\mathrm{PAH}$ patients have positive effects, where these will lead to improve endothelial function, physical activity capacity and quality of life. $^{2}$ In addition, these reduce the oxidative stress that occurs in blood vessels through increased activity of endothelial nitric oxide synthesis which will benefit for pulmonary vascular. ${ }^{2}$ Evaluation of the rehabilitation program in $\mathrm{PAH}$ patients are significant increase of 6MWD test distance, improved patient quality of life, maximal work rate, maximum heart rate, peak $\mathrm{VO}_{2}$ and $\mathrm{VO}_{2}$ threshold and anaerobic work rate (calculated by gas exchange in patients). ${ }^{2}$ These programs can be tolerated without reported incidents or adverse events. ${ }^{2}$ In this case, there was a significant increase of 6MWD distance for 30 days of exercise without complications during and after exercise.

The prescription of physical exercise program in $\mathrm{PAH}$ patients use the principles of FITT (Frequency, Intensity, Time and Type), depend on the patient's abilities, specific limitations of underlying illness as well as the goal of physical exercise. Physical exercise in $\mathrm{PAH}$ patients can be started by warming up for 5-10 minutes with low-moderate intensity then ended by cooling down for 3-10 minutes. This warming up period is useful for warm-up exercises of muscles, increased muscle temperature, oxygen exchange and increased transmission of nerve impulses. ${ }^{6}$

The cooling down period to restore the condition of the body after physical exercise, as well as avoiding the risk of post-action bronchial spasms. Physical exercise in $\mathrm{PAH}$ patients can be done in frequency of 3-5 times per week, with the supervision of cardiovascular rehabilitation expert. Duration of initial physical exercise time in $\mathrm{PAH}$ patients is recommended for 30 minutes (range 20-60 minutes) with a gradual increase up to $60-90$ minutes duration if the patient can tolerate exercise. ${ }^{6}$

The study by Newman and Robbins (2006) showed that PAH patients who underwent 12-15 weeks of physical exercise program, the average 6MWD test distance were $439 \pm 82$ meters. ${ }^{8}$ In this case, the average distance of 6MWD test was $400 \pm 82$ meters during 30 days of physical exercise. The 6MWD test is considered a test that can be well tolerated by the patient. The American College of Chest Physicians (ACCP) recommends a serial assessment of the physical and functional capacity of $\mathrm{PAH}$ patients using the 6MWD test to assess severity of thedisease and response to therapy. ${ }^{9}$ The 6MWD test measures the distance that the patient can walk on a flat surface within 6 minutes. The test also assess the patient's functional capacity at the submaximal level. ${ }^{10}$ Based on several previous studies, the distance of the 6MWD test was considered as an appropriate predictor of patient mortality. ${ }^{11}$

Oxygen saturation assessment during the 6MWD test can use pulse oximetry and oxygen saturation during the 6MWD test can be used to determine the degree of hypoxemia in PAH patients during the activity. The desaturation conditions during the 6MWD test is considered as a better predictor factor for mortality. Paciocco et al. (2001) published that $10 \%$ reduction of oxygen saturation during the 6MWD test predicted a higher mortality rate. $^{12}$ While other research stated that each $10 \%$ decrease of arterial oxygen saturation level during the 6MWD would increase $26 \%$ of mortality risk. In this case, there was no oxygen saturation decrease $>10 \%$ after exercise. ${ }^{10}$

Cardio Pulmonary Exercise Test (CPET) tests can be safely used in patients with advanced respiratory diseases, including $\mathrm{PAH}$, with some indications such as prognosis assessment, disability evaluation and monitoring response to therapy. ${ }^{13}$ The peak VO2 assessment during the CPET test is a gold standard in the assessment of PAH patients. In the CPET test, the patient will perform a training test using a static ergometer bicycle and the patient is asked to breathe through the mouthpiece. This test include assessment of the respiratory rate, $\mathrm{VE}, \mathrm{VO}_{2}, \mathrm{VCO}_{2}$, end tidal $\mathrm{PO}_{2}$, end tidal $\mathrm{PCO}_{2}, \mathrm{VE} / \mathrm{VO}_{2}$ and $\mathrm{VE} / \mathrm{VCO}_{2}$ and peripheral oxygen saturation at rest and during the test. Assessment is usually done within 3 
minutes when the patient at rest, 3 minutes when the patient do static ergometer and during progressive increases of the work rate. The test is stopped when the patients feel worsening of the symptoms. ${ }^{14}$ In this case, we did not perform CPET test.

The gas ventilation disorder precipitated by PAH conditions is affected by multiple factors and related to the severity of PAH. An increase of mean pulmonary artery pressure is the most important pathophysiological consequence of the condition, which leads to an imbalance between ventilation and perfusion.

The result of this condition is the increase of physiological dead space which is indicated by the increase of $\mathrm{VE} / \mathrm{VCO}_{2}$ ratio and the decrease or disappearance of partial pressure of ends tidal carbon dioxide (PET $\left.\mathrm{CO}_{2}\right) .{ }^{14}$ Increased pulmonary artery pressure may also lead to a decrease in blood flow to the left heart, thereby decreasing cardiac output for a minute. Increased pulmonary artery pressure will cause intra ventricular septum movement towards the left, this will affect the filling of the left ventricle so that there will decrease the cardiac output.

A decrease in cardiac output will be associated with decreasing peak $\mathrm{VO}_{2}$ and $\mathrm{VO}_{2}$ at the time of the ventilation threshold. Increasing the PAH severity will lead to decrease the red cell transit time in the pulmonary circulation so that oxygen diffusion will decrease. Further desaturation conditions in the arterial will enlarge the ventilation response to physical activity, increasing the ratio of $\mathrm{VE} / \mathrm{VCO}_{2}$ and decreasing PET $\mathrm{CO}_{2} \cdot{ }^{14}$

\section{CONCLUSION}

We reported 24-year-old woman with bidirectional shunt PDA with $\mathrm{PAH}$ who underwent 6MWD test and resulted in 90 meters at the beginning of the exercise. Exercises were done everyday then evaluated in 4 weeks. Physical exercise programs on $\mathrm{PAH}$ remain at risk for serious side effects and complications. Evaluation of physical capacity in $\mathrm{PAH}$ patients can be conducted with the 6MWD test and CPET.

\section{REFERENCES}

1. Galiè N., Torbicki A., Barst R., Dartevelle P., Haworth S., Higenbottam T., et al. 2009. Guidelines on diagnosis and treatment of pulmonary arterial hypertension. Eur Heart J, 25 : 2243-2278.

2. Mereles D., Ehlken N., Kreuscher S., Ghofrani S, Hoeper M., Halank, M. 2006. Exercise and respiratory training improve exercise capacity and quality of life in patients with severe chronic pulmonary hypertension. Circulation, 114 : 1482-1489.

3. Radi B., Joesoef AH., Kusmana, D. 2009. Rehabilitasi kardiovaskular di Indonesia. J Kardiol Indones, 30:43-54.

4. Hartopo AB, Dinarti LK. 2018. The shared pathogenesis of pulmonary artery hypertension. Acta Cardiol Indones, 4:22-27.

5. Shoemaker MJ, Wilt JF, Dasgupta R., Oudiz RJ. 2009. Exercise training in patients with pulmonary arterial hypertension. J Cardiopulmonal Phys Therapy, 20:198202.

6. Thompson WR., Gordon NF., Pescatello LS. 2009. ACSM Guidelines for exercise testing and prescription. Lippincott Williams and Wilkins.

7. American College of Sports Medicine. 2013. ACSM resource manual for guideline for exercise testing and prescription. Wolters Kluwer: Lippincott Williams \& Wilkins. pp: 575 - 599.

8. Newman J., Robbins I. 2006. Exercise training in pulmonary hypertension. Circulation, 114 : 1448-1449.

9. McGoon M., Gutterman D., Steen V., Pielsticer E. 2004. Screening, early detection, and diagnosis of pulmonary arterial hypertension. 
Chest, 126:14-34.

10. Miyamoto S., Nagaya N., Satoh T., Kyotani S., Sakamaki F., Fujita M. 2000. Clinical correlates and prognostic significance of six minute walk test in patients with primary pulmonary hypertension comparison with cardiopulmonary exercise testing. Am J Respir Crit Care Med, 161:487-492.

11. Solway S, Brooks D, Lacasse Y, Thomas S. 2011. A qualitative systematic overview of the measurement properties of functional walk tests used in the cardiorespiratory domain. Chest, 119:256-270.
12. Paciocco G., Martinez FJ., Bossone E., Pielsticker E., Gillispie B., Rupenfire M. 2001. Oxygen desaturation on the six minute walk test and mortality in pulmonary hypertension. Euro Respir J, 17:647-652.

13. American Thoracic Society. 2003. ATS Statement on Cardio Pulmonary Exercise Testing. 7599. J Respir Crit Care Med, 167:1451-1452.

14. Arena R., Lavie C., Milani, R., Myers, J., Guazzi, M. 2010.Cardiopulmonary exercise testing in patients with pulmonary arterial hypertension. J Heart Lung Transplant, 29:159-173. 